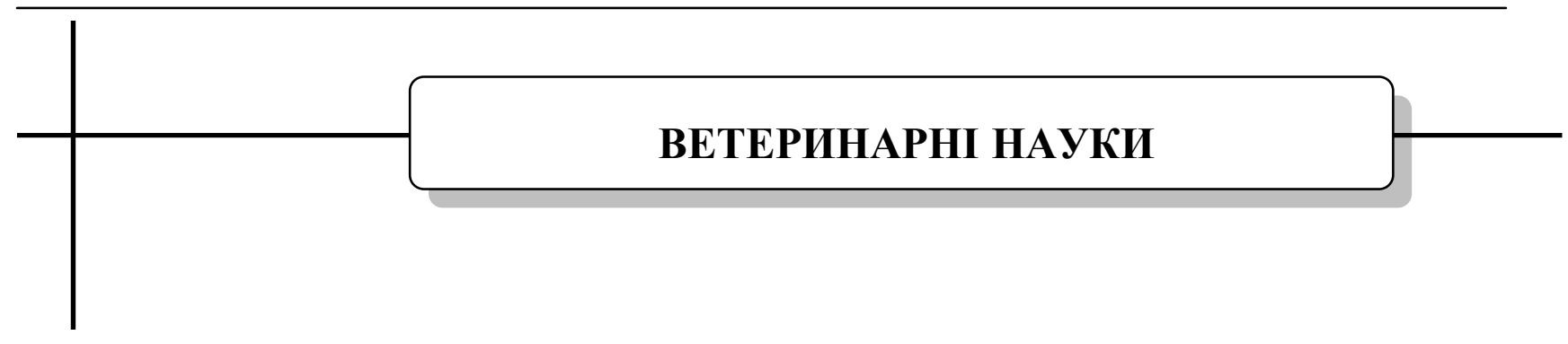

UDC 619:615.361:611.018.46:636.028

DOI: 10.15587/2313-8416.2018.121096

\title{
APPLICATION OF CYTOGENETIC RESEARCHES IN EFFICIENCY ASSESSMENT OF VACCINES AGAINST LEUKEMIA VIRUS IN CATTLE
}

\author{
(C) M. Drahulian, T. Dorosch, S. Kostenko
}

Вивчено вплив иммуногенів вірусу лейкозу великої рогатої худоби на цитогенетичні показники кісткового мозку в динаміці імуногенезу. Виявлено, щзо кожен препарат має свою специфічну дію, яка обумовлена структурними відмінностями вірусу лейкозу великої рогатої худоби. Метод циитогенетичних досліджень клітин кісткового мозку доцільно використовувати для оцінки безпеки та імуногенних властивостей препаратів ретровирусного походження

Ключові слова: генетичний моніторинг, вірус лейкозу ВРХ, імуногенез, миші, клітини кісткового мозку

\section{Introduction}

The use of genetic monitoring is a necessary stage of a preclinical study of the safety of the use of many medications, vaccines. Genetic monitoring is a scientific direction within which a methodology is developed to assess the appearance and accumulation of genotoxic substances in the body, to study the spectrum of their mutational effects and the ability to induce a particular type of genetic disturbance. One of the informative and fastest ways of indicating toxicity is a cytogenetic test based on counting the number of interphase cells with additional nuclear bodies (cells with micronuclei), cells with apoptosis, metaphase plates with chromosomal aberrations and other cytogenetic indices. The most frequently used for these purposes are highly specialized bone marrow cells.

In the 70s years of the last century, intensive development of genetic monitoring began within the toxicology program of research on environmental protection. At present, genetic monitoring is included as mandatory in many preclinical studies. Similar developments in the field of vaccinology in the scientific literature are poorly illuminated.

\section{Literature review}

In recent times the researches pay a special attention to analyzing the caryopathic effect of vaccine formulations, which cause a growth of cell count with cytogenetic changes in an organism [1,2]. According to the conceptual idea of F.M. Burnet, those particular changes in immune competent cells play an important role in clones of immunocytes formation derived from bone marrow, which compose the basic amount of Blymphocytes and their precursors [3]. Organism's Bsystem of immunity re-builds itself in a special way dur- ing the process of immune system stimulation [4]. In case of active action of antigen and composite components of vaccine formulations, the short-term or longterm structural changes in the genome of immune competent cells can occur at early stages of their development in the main organ of formation of blood cells - in the bone marrow [5]. The effect of the particular vaccines in cell cultures(in vitro) shows the growth of mitotic index and cells count with rounded and pathological nuclei and with other changes $[5,6]$.

Data analysis from the literature confirms the evidence of nonusage of the assessment method of cytogenetic changes in lymphoid cells of the bone marrow, which is the primary blood-forming organ, under the immunogens of retroviral origin.

\section{Aim and objectives of the research}

The main aim of our studies was to examine the influence immunogens of leukemia virus in cattle as a retrovirus representative on cytogenetic indices of the bone marrow of mice in immunogenesis dynamics and to evaluate the reasonability of using this particular approach in vaccinology of retroviral infection.

To achieve this aim, the following objectives have beenidentified:

1. Using genetic monitoring, compare the effect of each immunogens "Profileik 3" and "Profileik 4" on the mice;

2. Study the reaction of the bone marrow cells on the 7th, 14th, 30th and 60th days after the vaccination of mice;

3. Consider the mutational effects of each immunogens"Profileik 3" and "Profileik 4";

4. Assess the sensitivity of immunogens under study at different stages of formation of immunocompetent cells. 


\section{Materials and methods}

In order to determine the cytogenetic changes in immune competent cells of the bone marrow under the influence of inactivated vaccines against leukemia of cattle, our command constructed immunogens "Profileik 3" and "Profileik 4", which differ in their methodological approach of construction. The research was carried out in three groups of white mice (15 animal units in each group). Each animal from the experimental groups received the correspondent dual injection of vaccine at a dose of $0.1 \mathrm{~cm}^{3}$ at an interval of 7 days. Animals from the control group have remained intact. Cytogenetic stud- ies of the bone marrow cells of the femur were performed according to [7] on days 7, 14, 30, 60 on postinjection of immunogen. During the assessment of cytogenetic changes the following factors were taken into account: species-specific chromosome arrangement ( $2 \mathrm{n})$, presence of cells with micronuclei (MN) (Fig. 1, a), two nuclei (TN) (Fig. 1, b), and marker of apoptosis (AP) (Fig. 1, c), and mitotic index (MI).

The assessment of changes was performed in 3,000 cells. The metaphase frequency $(\%)$ with chromosomal aberrations (ChA) was identified according to the total metaphase plates count.

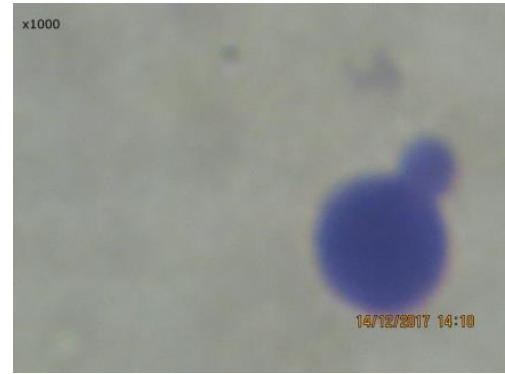

$a$

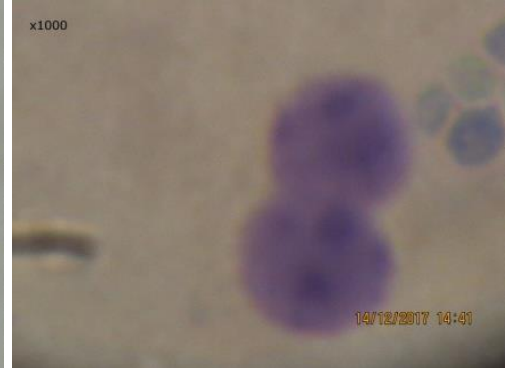

$b$

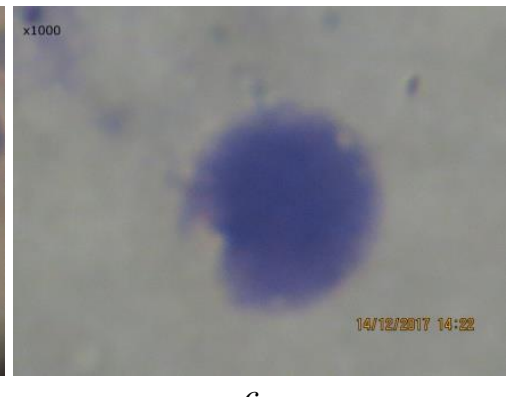

$c$

Fig. 1. Cytogenetic changes in the cells of the bone marrow of the mice: $a$-cell with micronuclei; $b$ - two nuclei cell; $c$ - cell with marker of apoptosis

Results of experiments were processed by methods of mathematical statistics. In our work we used the method of constructing variation series. We determined the mean value and the coefficient of variation and made a correlation analysis of the data. The calculation of results performed using Microsoft Excel 2003.

\section{Results}

At the period of experimental study (60 days), the experimental animals remained apparently healthy and showed no distinction in their physiological state and behavior in comparison with the control group of mice. No changes detected in mice at the site of injection of immunogens and isotonic sodium chloride solution.

During the assessment of the cytogenetic characteristics of cells it was established, that the normal species-specific chromosome arrangement $(2 n=40)$ was maintained during the entire period of the study under the effect of two inactivated vaccines against leukemia of cattle in majority of immunocytes of the red bone marrow of both experimental and control groups of mice.

The available data in the table indicates that on day 7 the mice, which were immunized with "Profileik 3" vaccine, had increase in the bone marrow in cells with MN by factor of 1.8 , in metaphase with ChA - by factor of 47.2, in $\mathrm{MI}$ - by factor of 1.4, in comparison with mice of the control group. Equally the decrease was observed in cells with TN by factor of 1.6 and in cells with AP by 2.2 times. The function of the bone marrow of the second group of mice changed in a different way. The day 7 after inoculation of the "Profileik 4" vaccine showed that the cells count with MN increased by factor of 3.3 , in metaphase with ChA increased by 34.9 and in MI - by 1.5 times. Compared to the mice vaccinated with the first immunogen upon ad- ministration of the second immunogen, no decrease of cells with $\mathrm{TN}$ in the bone marrow was observed, although the increase by factor of 2.2 was determined and was preserved the approximately equal level until the end of the research. Those differences may be stipulated by immunogen's structure.

At the time of construction of the medication "Profileik 4", the antigen carrier had smaller size, and this fact influenced the function of the bone marrow as for the assay of the cells with AP. No apoptosis cells detected per field of vision of the study drug from the bone marrow of mice from the second group at the initial stage of the research.

The first study of the bone marrow cells indicated the increasing adhesion between chromosomes in $0.83 \pm 0.4 \%$ of the MI in dividing bone marrow cells in the majority of mice of two experimental groups, and these indices respectively correlated with the cells with AP and giant cells: $\mathrm{r}=0.52$ and $\mathrm{r}=0.58$ at $0.95<\mathrm{P}<0.99$. Although the giant cells count did not exceed the average population-based level in the animals from the experimental groups.

7 days after the second administration of the "Profileik 3" vaccine, and before the end of the experimental period (60 days), the restoration was observed up to the initial level of number of cells with $\mathrm{TN}$, and cells with $\mathrm{MN}, \mathrm{ChA}$ and MI.

Consequently, the repeated injection of immunogen does not cause such essential changes in the function of the bone marrow of mice. The similar situation could be observed when using the "Profileik 4" vaccine. The exceptional situation was in cells with $\mathrm{TN}$, as on day 30 the increase by factor of 2.3 was shown in comparison with the initial level, and day 60 showed the decrease by factor of 0.9 relating to the previous study (Table 1 ). 
Table 1

Cytogenetic indices of the bone marrow of white mice $(n=3)$ under the effect of the inactivated vaccines "Profileik 3" and "Profileik 4" against leukemia virus in cattle

\begin{tabular}{|c|c|c|c|c|c|c|}
\hline \multirow{2}{*}{ Medication } & \multirow{2}{*}{$\begin{array}{c}\text { Cytogenetic } \\
\text { changes }\end{array}$} & \multicolumn{5}{|c|}{ Day of experience } \\
\hline & & $\begin{array}{l}\text { Before injec- } \\
\text { tion of m-tion }\end{array}$ & $\begin{array}{l}7 \text { (after } 2 \text { injec- } \\
\text { tion of } \mathrm{m} \text {-tion) }\end{array}$ & 14 & 30 & 60 \\
\hline \multirow{5}{*}{ Profileik 3} & MN \%o & $2,8 \pm 0,6$ & $5,0 \pm 0,57$ & $1,6 \pm 0,3$ & $2,6 \pm 0,3$ & $1,0 \pm 0,0$ \\
\hline & TN \%o & $19,3 \pm 0,3$ & $12,3 \pm 0,8$ & $12,6 \pm 0,8$ & $17,6 \pm 3,1$ & $18,0 \pm 1,5$ \\
\hline & AP \%o & $1,3 \pm 0,3$ & $0,6 \pm 0,33$ & $0,5 \pm 0,2$ & $0,3 \pm 0,3$ & 0 \\
\hline & MI \%o & $40,0 \pm 5,5$ & $57,3 \pm 2,9$ & $39,0 \pm 3,0$ & $33,6 \pm 0,8$ & $32,3 \pm 0,8$ \\
\hline & $\begin{array}{c}\text { Metaphase plates } \\
\text { with ChA \% }\end{array}$ & $0,13 \pm 0,03$ & $6,14 \pm 0,61$ & $2,17 \pm 0,16$ & $0,42 \pm 0,72$ & $0,59 \pm 0,06$ \\
\hline \multirow{5}{*}{ Profileik 4} & MN \%o & $2,4 \pm 0,6$ & $8,0 \pm 0,57$ & $2,6 \pm 0,6$ & $4,6 \pm 0,8$ & $1,3 \pm 0,3$ \\
\hline & TN \%o & $21,3 \pm 0,3$ & $46,3 \pm 2,4$ & $52,3 \pm 2,3$ & $49,6 \pm 4,1$ & $45,3 \pm 1,4$ \\
\hline & AP \%o & $1,4 \pm 0,3$ & 0 & $0,6 \pm 0,1$ & $1,6 \pm 0,3$ & $0,6 \pm 0,3$ \\
\hline & MI \%o & $43,0 \pm 5,5$ & $65,0 \pm 1,5$ & $41,0 \pm 0,5$ & $41,0 \pm 3,2$ & $37,3 \pm 0,8$ \\
\hline & $\begin{array}{c}\text { Metaphase plates } \\
\text { with ChA \% }\end{array}$ & $0,15 \pm 0,03$ & $5,23 \pm 0,82$ & $2,90 \pm 0,17$ & $0,68 \pm 0,19$ & $0,10 \pm 0,21$ \\
\hline \multirow{5}{*}{ Control } & MN \%o & $2,6 \pm 0,6$ & $2,8 \pm 0,2$ & $2,8 \pm 0,4$ & $2,4 \pm 0,8$ & $2,6 \pm 0,4$ \\
\hline & TN \%о & $20,6 \pm 0,4$ & $21,3 \pm 0,3$ & $22,4 \pm 2,6$ & $22,8 \pm 1,2$ & $21,8 \pm 3,6$ \\
\hline & AP \%o & $1,2 \pm 0,8$ & $1,3 \pm 0,3$ & $1,8 \pm 0,5$ & $1,6 \pm 0,2$ & $1,4 \pm 0,3$ \\
\hline & MI \%o & $40,0 \pm 5,5$ & $41,0 \pm 3,6$ & $40,0 \pm 0,5$ & $40,6 \pm 0,8$ & $41,0 \pm 3,2$ \\
\hline & $\begin{array}{c}\text { Metaphase plates } \\
\text { with ChA \% }\end{array}$ & $0,13 \pm 0,08$ & $0,14 \pm 0,03$ & $0,16 \pm 0,03$ & $0,14 \pm 0,06$ & $0,14 \pm 0,08$ \\
\hline
\end{tabular}

Thus, the mice of the first experimental group had a dynamical decrease in cells with AP up to the complete absence in the final study, and in the mice of the second group the disappearance of cellular state under study was revealed only on day 7 of the research. Following the second administration of the drug, the state of apoptosis in animals of the second group reached the parameters of mice of the control group.

Authors of publications [8,9] established that the regulation of immune processes is associated with the phenomenon of apoptosis of immune competent cells. Thereof the decrease of apoptosis rate in the bone marrow cells of experimental mice may be determined by their dynamic differentiation, which is connected with the building of an antigen-specific composite immune system, and not least because of realization of system's effector functions and degenerative processes in the immune competent organ $[10,11]$. According to the study results it is possible to characterize the processes of development of cellular homeostasis on the organism level [12] and the increase of intercellular junctions, which may refuse to develop the apoptosis [13].

Hereby basing on the determined regularities of the cells' cytogenetic characteristics, it is necessary to consider changes in the index of mutagenicity as a structural alert of its immunogenicity, rather than an indicator of the drug toxic effect according to A. A. Yarilin [4]. The author indicates that vaccinal mutagenesis encourages the differentiation of B lymphocytes into IgG secreting cells and provides emerging of clones closely related to antigens in comparison with early B cell precursors. The survival factor of Bcl-2 cells is expressed in case of close relation of the B-lymphocyte receptors to the antigen. This fact might help to explain the revealed decrease in apoptosis in the immune competent cells of the bone marrow after injection of the immunogen in the experimental group of mice (Table 1).

According to the literature surveys, there exist a close relationship between the chromosomal aberrations count and the activity of mitosis, which promotes the development of cells with MN [12] and the formation of excess DNA [14]. In this way the revealed increase in micronuclei quantity testifies the quantitative changes in DNA in a living cell.

The difference in indices of animal of two experimental groups under study can be attributed to the difference in the methodical approach of vaccine preparations' constructing, which defined not equal effect on the humoral and cell-mediated units of the immune system. This reflected again that the mutagenic changes in cells of the bone marrow of mice during the research generally occurred from the primary response.

\section{Conclusions}

The results we obtained in the genetic monitoring of immunogens "Profileik 3" and "Profileik 4" on the mice gave us the opportunity to conclude:

1. First of all the data resulting from the study certifies a high functional response of the bone marrow in initial 7 days after the first inoculation of the immunogens under study.

2. Secondly, each antigenic preparation has its particular specific actions caused by structural differences of the biological carrier of the antigen of leukemia virus of cattle.

3. Thirdly, it was established a high sensitivity of research on assessment of vaccine against retroviruses efficiency on the immunogenesis system at the initial stage of the formation of immune competent cells.

4. And the final conclusion reveals that the vaccines cause interim signs of mutagenesis in the lymphoid cells of the bone marrow. 


\section{References}

1. Cell proliferation blocking and mitosis pathology in cells infected by cytomegalovirus / N. E. Fedorova et. al. // Academy of science abstracts. 2003. Vol. 392, Issue 4. P. 552-555.

2. Cerkhezia S. E., Mykhaylova G. R., Gorshunova L. P. Chromosome research of bone marrow cells of mice which took anti rabies vaccine // Cytology and genetics. 1980. Vol. 14, Issue 4. P. 67-70.

3. Infectious caryopathology / I. N. Ilinskykh et. al. // Tomsk: Tomsk university press. 2005. 168 p.

4. Yarylin A. A. Apoptosis and its role in an organism as a whole // Glaucoma. 2003. Vol. 2. P. 46-54.

5. Serenot Ch. K. Studies related to morphological changes k-562 cell culture nuclei influenced by viral vaccine // Thesis collection related to the topics of 64-th International scientific students' conference named after N. I. Pirogov. 2005. P. 52.

6. Sivakova T. N., Mylnikova E. A. Caryopathic effect of Nobivak Rabies vaccine on bone marrow cells and white mice testis // Fundamental medical-biological science and practical healthcare. 2010. P. 46-49.

7. Methodological guidance on cytogenetic testing in swine breeding / A. F. Yakovlev et. al. Kharkiv: Ukraine Veterinary Theoretical research institute. 1990. $24 \mathrm{p}$.

8. Interleukin-4 inhibits tumor necrosis factor- $\alpha$-induced and spontaneous apoptosis of biomaterial-adherent macrophages / Brodbeck W. G. et. al. // Journal of Laboratory and Clinical Medicine. 2002. Vol. 139, Issue 2. P. 90-100. doi: 10.1067/ mlc.2002.121260

9. Spontanous ex vivo apoptosis of peripheral blood mononuclear cells in patients with head and neck cancer / T. Saito et. al. // Clinical Cancer Research. 1999. Vol. 5. P. 1263-1273.

10. Il'inskykh N. N. Cytogenetic analysis of consequences of infectious mutagenesis complimented by condition of immunoreactivity of an organism: abstract PhD thesis. Tomsk, 1984. $42 \mathrm{p}$.

11. Ingel F. I. Perspectives of micronuclear test in human lymphocytes cultivated in cytogenetic block conditions. Part 1: Cell proliferation // Ecological Genetics. 2006. Vol. 4, Issue 3. P. 7-19. doi: 10.17816/ecogen437-19

12. Ilin D. A. Formation of micronuclei // Natural science and humanism. 2006. Vol. 3. P. 58.

13. Yarylin A. A. Apoptosis and its role in immune processes // Immunology. 1996. Vol. 6. P. 10-23.

14. Shimizu N., Kamezaki F., Shigematsu Sh. Tracking of microinjected DNA in live cells reveals the intracellular behavior and elimination of extrachromosomal genetic material. Nucleic Acids Research. 2005. Vol. 33, Issue 19. P. 6296-6307. doi: 10.1093/nar/gki946

Дата надходження рукопису 07.11.2017

Maria Drahulian, PhD, Researcher, Department of Genetics, Breedingand Biotechnology Animals, National University of Life and Environmental Sciences of Ukraine, Heroiv oborony str., 15, Kyiv, Ukraine, 03041 E-mail: parus_major@ukr.net

Tetiana Dorosch, PhD, Assistant, Department of Therapy and Clinical Diagnosis, National University of Life and Environmental Sciences of Ukraine, Heroiv oborony str., 15, Kyiv, Ukraine, 03041

E-mail: ttatjana@bigmir.net

Svitlana Kostenko, Doctor of Biological Sciences, Professor, Department of Genetics, Breeding and Biotechnology Animals, National University of Life and Environmental Sciences of Ukraine, Heroiv oborony str., 15, Kyiv, Ukraine, 03041

E-mail: svitlanakostenko@i.ua 